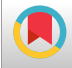

\title{
Exercise Training and Breast Cancer-Related Lymphedema: A
}

\section{Systematic Review}

\author{
Saeed Naghibi, ${ }^{1,}$ and Fatemeh Varshoie Tabrizi ${ }^{2}$ \\ ${ }^{1}$ Department of Exercise Physiology, University of Payame Noor, Tehran, Iran \\ ${ }^{2}$ Reza Radiation Oncology Center, Mashhad, IR Iran \\ "Corresponding author: Saeed Naghibi, Nakhl St, Lashkarak Highway, Tehran, Iran. Tel: +98-23320000, E-mail: sdnaghibi@yahoo.com
}

Received 2017 April 24; Accepted 2017 October 29.

\begin{abstract}
Context: Despite the improvements that have been made in treatment of breast cancer, upper-limb lymphedema is still an unsolved problem in the treatment of women with breast cancer. Upper extremity lymphedema may accompany with decreased in shoulder range of motion and strength, and also pain. Nowadays, exercise training acts as a treatment method to control lymphedema in breast cancer survivors. Therefore, this study reviews the results of the applied studies in this field to survey the influences of exercise training on lymphedema and to determine its related symptoms in women with breast cancer.

Data Sources: Literature investigation was conducted on August 1st, 2016 using PUBMED, MEDLINE, CINAHL, and Google Scholar databases.

Study Selection: Randomized and nonrandomized controlled trials published in English were included. Twelve trails met inclusion criteria.

Data Extraction: Data were extracted in a standardized manner into the predefined table. Then, quality of the studies was evaluated using the guide to community preventive services tool.

Conclusions: It can be seen that a few studies have examined the effect of exercise training on lymphedema to conduct a review study. So, lymphedema continues to be a problem for breast cancer survivors. According to most studies, aerobic, resistance and stretching training programs had no influence on the volume and circumference of arm in lymphedema cancer patients, but the training had a noticeable influence on quality of life
\end{abstract}

Keywords: Exercise Training, Breast Cancer-Related Lymphedema, Breast Cancer Survivors

\section{Context}

In western countries, incidence and death by breast cancer are considered as an important subject and many types of research have been conducted in this field (1-3). In recent decades, medical improvements have led to increasing in the number of breast cancer survivors, and breast cancer is no longer an uncontrollable disease (3). Thus, development of cancer care and medication in these patients could increase the lifetime and improve the quality of life.

Treatment of these patients consists of surgery and radiotherapy, which these procedures for breast cancer can cause short-term pain and tenderness in the treated area. Also, the skin in the breast area may feel tight, and the muscles of the arm may feel stiff or weak (4-9). Recent studies have also reported that probably $50 \%$ of cancer patient survivors are exposed to lymphedema risk over a period of 20 years after treatment (10). The UK started assessment of the quality of life of 2,208 breast cancer patients in a 5-year period (11). About one third of the patients complained of pain in their breast and arm (11).

One of the problems in breast cancer survivors after mastectomy is lymphedema and pain in the arm. There are many treatments for lymphedema, but none of them could be considered as a complete treatment (12). It can be seen that exercise training is not a conventional method for controlling lymphedema, and some experts even prohibit this treatment. A few researches have studied the effect of exercise training on lymphedema treatment. Therefore, this study was conducted to review and summarize the results of studies applied on exercise intervention and breast cancer lymphedema. This study also aims to specify the type and amount of adequate exercise training in patients with Lymphedema.

Previous reviews on exercise training intervention and breast cancer patients had focused on special consequences and groups, such as physical fitness, (13) body composition, (14) immune function, (15) fatigue, (16) and quality of life (17). There are a few prior studies that have 
reviewed the effect of exercise training on lymphedema in patients with breast cancer. This systematic review examines the evidence that exercise training intervention, is useful to help lymphedema in patients with breast cancer and improve their physiological and psychosocial conditions. Another purpose of this study is to evaluate the effect of different types of exercise training on breast cancerrelated lymphedema.

\section{Methods}

\subsection{Search Strategy for Identification of Relevant Studies}

In this study, literature review was applied by searching in MEDLINE, CINAHL, and Google Scholar on $1 \mathrm{Au}-$ gust 2016 using search related keywords including cancer, radiotherapy, chemotherapy, breast cancer and exercise training, exercise therapy, physical activity, physical training and lymphedema, lymph node, upper extremity edema and controlled trial, randomized, placebo, randomly or group (an example search carried out in Pub Med database was observed in Table 1). It needs to be stated that relevant reference lists were also manually searched. The selection of full-text articles was based on the search strategy to identify studies from electronic databases presented in Table 2.

\subsection{Selection Method}

To be included in this review, a randomized and nonrandomized controlled trial should be focused on women adult patients with breast cancer (aged $\geq 18$ ) and it includes exercise intervention group and the control lymphedema group. Also, studies must be published in the English language. Figure 1 shows the flowchart of the methodology implemented in this study.

\subsection{Methodological Quality Assessment and Data Extraction}

Summary tables were designed based on the guide to community preventive services (TGCPS) (18). The summary tables have described the interventions of the exercise training, participants' specifications, measuring results, and conclusions of the studies. Study quality was evaluated by 10 questions: (1) query of the study; (2) competency criteria; (3) proper involvement of intervention groups; (4) check groups baseline similar properties; (5) control for confounders; (6) full description of interventions and results; (7) blinded results evaluation; (8) evaluation results with correct methods $(18,19)$. A study with at least 5 out of 10 points was considered as a high-quality study. In this review, only high-quality studies were taken into account.
Table 1. Example Search Carried Out in Pub Med. Date of Search 01/08/2016

\begin{tabular}{|c|c|c|}
\hline$\#$ & Searches & Results \\
\hline $\mathbf{1}$ & Cancer [MeSH Major Topic] & 2.514 .776 \\
\hline 2 & Radiotherapy [Title/Abstract] & 144.512 \\
\hline 3 & Chemotherapy [Title/Abstract] & 286.462 \\
\hline 4 & Breast cancer [Title/Abstract] & 327.288 \\
\hline 5 & 1 or 2 or 3 or 4 & 2.688 .910 \\
\hline 6 & Exercise training [Title/Abstract] & 331.449 \\
\hline 7 & Exercise therapy [Title/Abstract] & 92.793 \\
\hline 8 & Physical activity [Title/Abstract] & 427.660 \\
\hline 9 & Physical training [Title/Abstract] & 160.083 \\
\hline 10 & 6 or 7 or 8 or 9 & 98.102 \\
\hline 11 & Lymphedema [Title/Abstract] & 12.724 \\
\hline 12 & Lymph node [Title/Abstract] & 221.455 \\
\hline 13 & Upper extremity edema [Title/Abstract] & 2.066 \\
\hline 14 & 11 or 12 or 13 & 121.022 \\
\hline 15 & Controlled trial [Title/Abstract] & 674.066 \\
\hline 16 & Randomized [Title/Abstract]) & 729.956 \\
\hline 17 & Placebo [Title/Abstract]) & 192.674 \\
\hline 18 & Randomly [Title/Abstract]) & 258.481 \\
\hline 19 & Group [Title/Abstract] & 2.654 .195 \\
\hline 20 & 15 or 16 or 17 or 18 or 19 & 2.584 .097 \\
\hline 21 & 5 and 10 and 14 & 33 \\
\hline 22 & Limit to the English language & 31 \\
\hline
\end{tabular}

Table 2. Search Strategy to Identify Studies From Electronic Databases

\begin{tabular}{ll}
\hline Strategy & \\
\hline Population & Patients with breast cancer-related lymphedema \\
\hline Intervention & Exercise training, exercise therapy, or physical activity \\
Comparator & Non-exercise patients \\
Outcomes & Clinical effectiveness \\
Study Designs & $\begin{array}{l}\text { Non-randomized controlled trial; randomized controlled } \\
\text { trial; uncontrolled trial; }\end{array}$ \\
\hline
\end{tabular}

\subsection{Data Synthesis}

First, information of the selected studies was summarized (Table 2). The summary tables show the interventions, results, and conclusions of the researches. Due to the lack of precise control and incongruity of the study designs, a meta-analysis on the results was not carried out in this review. 


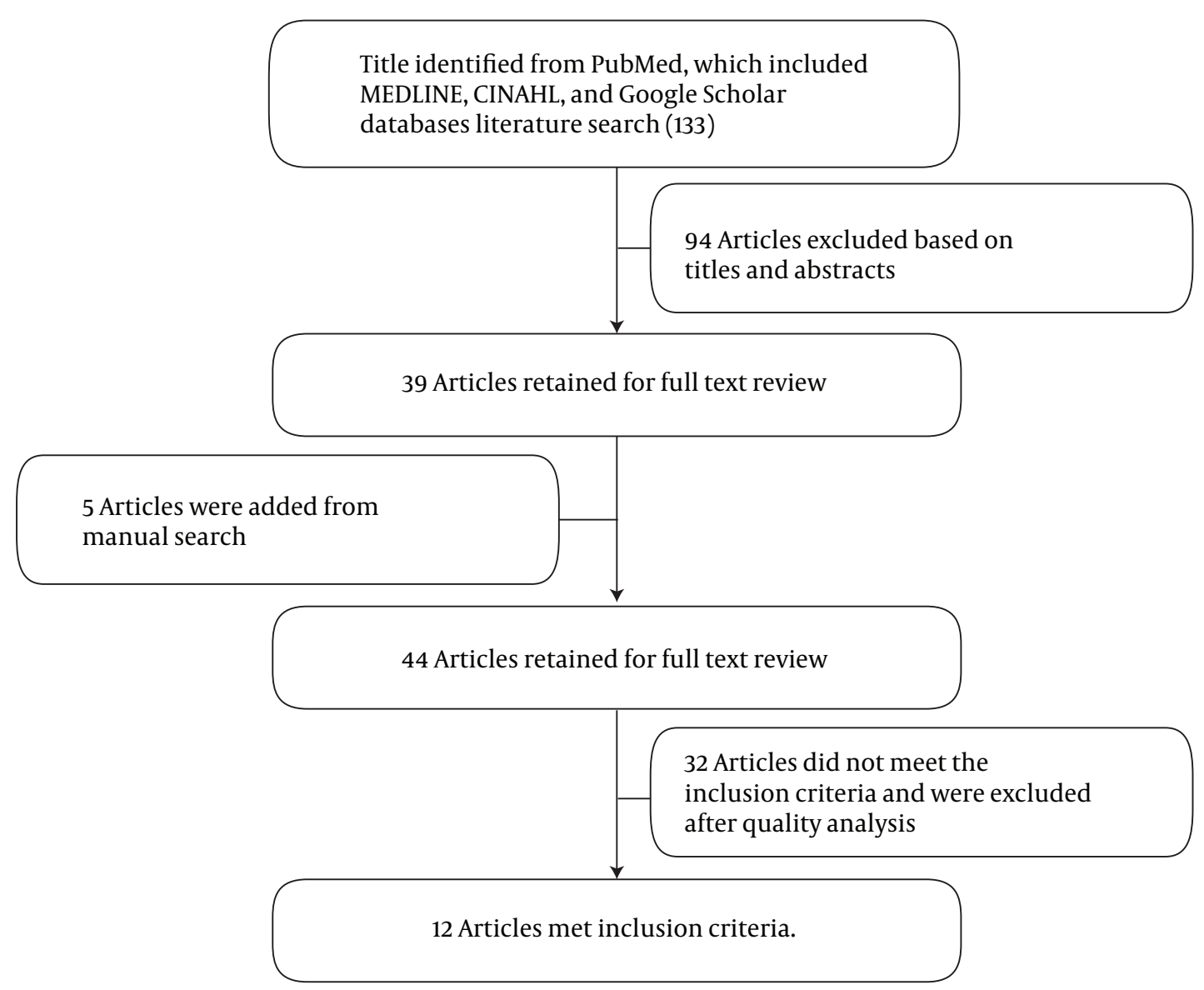

Figure 1. Flowchart of the Methodology Implemented in This Study

\section{Results}

Thirty-two relevant researches were accepted. According to the inclusion/exclusion criteria, twelve researches were then selected. These studies include eight randomized controlled trials, 2 non-randomized controlled trials, and 2 uncontrolled trials. Study descriptions and outcomes were exposed in Table 3.

\section{Conclusions}

Breast cancer survivors confront some problems due to their illness and therapeutic methods. Physical fitness and quality of life deteriorate and risk for recurrence of cancer increases. Most of the medics prescribed for cancer patients and survivors are to keep away exercise training. However, some new studies on the effects of physical activity on cancer patients have challenged this recommendation. These studies have reported that exercise training during and after adjuvant cancer therapy is safe and efficient for lymphedema management. They have concluded that physical training could improve physical fitness, and thereby increase the quality of life (20-22).

Courneya et al. (2009) suggested that VO2peak improvements by exercise training are the best technique to improve physical fitness and quality of life in lymphedema patients (20). Furthermore, exercise did not interfere with ability or desire of cancer patients to complete their treatments. Their findings showed that quality of life was decreased in most of the cancer patients, and this was an important problem of these patients in long-term. According to the results of this research, exercise training can diminish the problem by improving a physiological aspect of the body (23). Therefore, exercise during chemotherapy and after the treatment is effective for lymphedema patients.

McKenzie and Kalda (2003) reported that exercise is not effective to change the arm volume in lymphedema 
Table 3. of of Study Descriptions and Outcomes

\begin{tabular}{|c|c|c|c|c|c|}
\hline $\begin{array}{l}\text { Reference (Author, Year, and } \\
\text { Country) }\end{array}$ & Study Design & $\begin{array}{l}\text { Study Population } \\
\text { Descriptions }\end{array}$ & No. & Intervention Details & Results \\
\hline Courneya et al. 2009, Canada & RCT & Two armed patients & 122 & $\begin{array}{l}12 \text { weeks supervised aerobic } \\
\text { exercise training }\end{array}$ & $\begin{array}{l}\text { Effective role of exercise } \\
\text { training to manage } \\
\text { lymphedema patients }\end{array}$ \\
\hline Courneya et al. 2009, Canada & RCT & Lymphedema patients & 122 & $\begin{array}{l}12 \text { weeks supervised aerobic } \\
\text { exercise training }\end{array}$ & $\begin{array}{l}\text { Exercise improved body } \\
\text { composition and quality of life } \\
\text { in patients with lymphedema }\end{array}$ \\
\hline Ahmed et al. 2006, USA & RCT & $\begin{array}{l}\text { Breast cancer women after } \\
\text { mastectomy }\end{array}$ & 78 & 24 weeks resistance training & $\begin{array}{l}\text { Exercise did not increase the } \\
\text { risk of lymphedema }\end{array}$ \\
\hline Do et al. 2015, Korea & RCT & Lymphedema patients & 44 & $\begin{array}{l}8 \text { weeks resistance training } \\
\text { with } 1 \text { or } 2 \text { weeks complex } \\
\text { decongestive therapy }\end{array}$ & $\begin{array}{l}\text { Training improves function and } \\
\text { strength of arm but does not } \\
\text { change its volume }\end{array}$ \\
\hline Schmitz et al. 2010, USA & RCT & $\begin{array}{l}\text { Cancer survivors at risk for } \\
\text { breast cancer-related } \\
\text { lymphedema }\end{array}$ & 154 & $\begin{array}{l}12 \text { weeks of supervised } \\
\text { resistance training and } 36 \\
\text { weeks unsupervised exercise }\end{array}$ & $\begin{array}{l}\text { Exercise did not increase } \\
\text { lymphedema }\end{array}$ \\
\hline Schmitz et al. 2010, USA & RCT & $\begin{array}{l}\text { Breast-cancer survivors with } \\
\text { stable lymphedema of the arm }\end{array}$ & 141 & $\begin{array}{l}\text { Resistance training for twice a } \\
\text { week }\end{array}$ & $\begin{array}{l}\text { Training improves strength but } \\
\text { does not have any effects on } \\
\text { lymphedema }\end{array}$ \\
\hline Bok, 2016, Korea & RCT & $\begin{array}{l}\text { Breast cancer-related } \\
\text { lymphedema }\end{array}$ & 32 & $\begin{array}{l}\text { Progressive resistance exercise } \\
\text { by } 0.5 \mathrm{~kg} \text { dumbbell while } \\
\text { wearing a compression } \\
\text { stocking for } 8 \text { weeks }\end{array}$ & $\begin{array}{l}\text { Progressive resistance exercise } \\
\text { reduced arm circumference by } \\
\text { decreasing subcutaneous tissue } \\
\text { thickness and increasing } \\
\text { muscle thickness }\end{array}$ \\
\hline $\begin{array}{l}\text { Hammer and Fleming, 2007, } \\
\text { USA }\end{array}$ & NRCT & $\begin{array}{l}\text { Breast cancer patients with } \\
\text { lymphedema }\end{array}$ & 135 & $\begin{array}{l}8 \text { weeks training for range of } \\
\text { motion with compression } \\
\text { garments and manual massage }\end{array}$ & $\begin{array}{l}\text { Intervention reduced } \\
\text { lymphedema and pain }\end{array}$ \\
\hline Simonavice, 2016, USA & NRCT & $\begin{array}{l}\text { Breast cancer survivors (BCS) } \\
\text { aged } 64 \pm 7\end{array}$ & 27 & $\begin{array}{l}24 \text { weeks resistance exercise } \\
\text { training (RT) two days a week }\end{array}$ & $\begin{array}{l}\text { No significant changes was } \\
\text { revealed in arm circumferences }\end{array}$ \\
\hline Buchan et al. 2016, Australia & UCT & $\begin{array}{l}\text { Lymphedema breast cancer } \\
\text { women }\end{array}$ & 41 & $\begin{array}{l}\text { a resistance or aerobic-based } \\
\text { exercise training intervention } \\
\text { for } 12 \text { weeks }\end{array}$ & $\begin{array}{l}\text { No significant differences in } \\
\text { lymphedema status was seen } \\
\text { between groups }\end{array}$ \\
\hline Singh et al. 2016, Australia & UCT & $\begin{array}{l}\text { Women with breast } \\
\text { cancer-related lymphedema }\end{array}$ & 41 & $\begin{array}{l}\text { Aerobic or resistance training } \\
\text { with compression garments }\end{array}$ & $\begin{array}{l}\text { Intervention did not change } \\
\text { cancer-related lymphedema }\end{array}$ \\
\hline Mckenzie et al. 2003, Canada & RCT & $\begin{array}{l}\text { Breast cancer survivors with } \\
\text { unilateral upper extremity } \\
\text { lymphedema }\end{array}$ & 14 & $\begin{array}{l}8 \text { weeks resistance and aerobic } \\
\text { upper body training }\end{array}$ & $\begin{array}{l}\text { Exercise did not modify } \\
\text { lymphedema but increased } \\
\text { quality of life }\end{array}$ \\
\hline
\end{tabular}

Abbreviations: No., number of subjects; NRCT, non-randomized controlled trial; RCT, randomized controlled trial; UCT, uncontrolled trial.

cancer patients, but they may experience an increase in quality of their life (24). They reported that harmfulness of strength training for patients with lymphedema is an abuse belief. Thus, the lack of effectiveness of the intervention may be due to small sample size or inadequate exercise training time or intensity resulting in statistically significant changes.

Eight- week moderate intensity resistance exercise program along with 1 or 2 weeks of intensive complex decongestive therapy for patients with breast cancer-related lymphedema improve function and strength of arm without changing the volume (25). Also, Simonavice et al. (2016) assessed the arm circumferences of 27 breast cancer patients during 24- week resistance training (26). Their findings implied that resistance exercise training can be a safe activity for breast cancer patients with lymphedema.

Nelson (2016) reviewed the effect of resistance training on lymphedema in breast cancer patients. In 6 randomized controlled trials, involving 805 breast cancer survivors, he concluded that breast cancer survivors can perform high-enough intensity resistance exercise training to increase strength muscle without any changes in lymphedema status (27). Keilani et al. (2016) reviewed the influence of the resistance training on secondary lymphedema in breast cancer patients (28). As a conclusion remark, it was seen that none of the included articles showed negative effects on arm circumference and its volume. The intensity of resistance training in the included studies was moderate to high. Singh et al. (2016) in their review article, mentioned that patients with lymphedema can exer- 
cise safely without fearing of escalation of lymphedema. However, there is insufficient evidence for using compression garments during training (29).

Buchan et al. (2016) studied the effect of resistance or aerobic training on the severity of lymphedema in cancer patients. Their results showed that exercise did not cause any change in lymphedema severity, but the shoulder performance was improved (30). Findings of their study suggested that the mode of exercise training is not important given the severity of lymphedema. Therefore, to determine the mode of exercise for patients with lymphedema, individual's background, medical considerations and functional requirements must be considered.

In some previously studies in this field, arm composition was controlled by comparison between volume and circumference of two hands $(12,31)$. However, these measurement techniques were not able to show which tissue is changed by exercise training intervention. Regular exercise increases muscle size and decreases fat tissue. Although arm volume did not alter in most of the trails, the positive effect of exercise training may be covered by arm composition changes in lymphedema cancer patients.

In answering the above-mentioned ambiguity, Bok et al. (2016) studied the ultrasonic influence of progressive resistance training on lymphedema responses in breast cancer patients (32). They observed that resistance exercise training can reduce subcutaneous fat and arm circumferences in patients. Also, resistance exercise training significantly increased the arm hypertrophy. They reported in the treatment process of patients with breast cancer-related lymphedema that progressive resistance exercise training with complex decongestive physiotherapy did not cause additional swelling. They concluded that resistance exercise may reduce arm circumference by decreasing subcutaneous tissue thickness and increasing muscle thickness.

Overweight and fatness can cause interference in evaluating the changes in volume and circumference of the arm (31). They can cover the changes of lymphedema by increasing hypertrophy of normal arm rather than a lymphatic arm, or increasing volume of two arms. So, in these trails, measurement of real changes in arm volume is difficult and requires modern equipment (24).

In previous studies, although the lymphedema did not change, patients reported the desirable effect of exercise on their lymphatic arm. But this improvement was not measurable.

Researchers said the exercise training improved the health in ways that were not measurable with these methods. They concluded that exercise training results in softening of hardened areas, pain reduction and swelling in everyday activities, and reconstruction of the tendons of the hand. Many participants continued training after the end of the study period (24).

Ahmed et al. (2006) reported average changes of four round-arm measurements after 24 weeks of weight training in lymphedema-related cancer patients were less than two centimeters (33). They concluded that resistance and aerobic exercises are better than sedentary lifestyle for lymphedema-related cancer patients. Exercise through multiple physiological processes may help to control lymphedema and related symptoms. There are several feasible biologic mechanisms in which exercise training may help prevent lymphedema or may control its symptoms. Exercise training helps to enhance lymph flow and increase protein resorption (34-36). Lymph flow is increased by reducing the intra-thoracic pressure accompany with inspiration (37); therefore, increase in pulmonary activity during exercise training may reduce swelling (38). Furthermore, Svensson et al. (1994) showed that arm venous drainage has some problem in breast cancer survivors with lymphedema (39); thus, stretching exercises may reduce tissue hardness, and trapped lymph fluid (38).

Singh et al. (2016) surveyed the effect of 12 weeks of exercise training with a compression bandage on lymphedema changes in women with breast cancer (40). They observed compression use during exercise training had no positive or negative effect on breast cancer-related lymphedema. On the other hand, Hammer et al. (2007) observed $31 \%$ reduction in mean initial lymphedema volume after twice a week for 8- week complete decongestive therapy(CDT) that consisted of manipulation massage therapy, use of compression bandage, and stretching training (41). The degree of pain was also decreased from an average of 6.9 to 1.1 after treatment (numerical scale from 0 to 10 ).

Courneya et al. (2009) reported that some clinical variables may be able to predict the useful responses of training in lymphedema-related cancer patients (42). These clinical variables included having no training background, being unmarried, having no overweight or obesity, or being in a good health situation. Furthermore, other contributing factors included auxiliary dissection, breast radiotherapy, axilla radiotherapy, pathological nodal status, obesity, and stage of the tumor. So, future trials should be focused on patient preference, social support, age, disease stage, and general health as potential moderators of exercise training responses in cancer patients, especially while designing future exercise trials and/or recommending exercise to lymphedema patients.

There are several reasons to prescribe an incrementally controlled training program for the treating protocol of breast cancer-related lymphedema (43). Lymph fluid flows over both active and passive forces. Nowadays, passive treatment methods are commonly used to control lymphedema in breast cancer survivors. The passive methods 
contain manipulating lymphatic therapy, treating massage, use of compress pump, recessive sleeves, and elevation of the limb. Exercise training method is an active force for the treatment of lymphedema. These active forces contain the pump of skeletal muscle, the pump of the respiratory, and arterial pulse (24). The active muscles during exercise cause increase of blood and lymph pump in the body (36). Exercise training should also stimulate the contraction of the lymph vessels by the sympathetic system. Exercise training by these internal contractions resets the sympathetic system to these vessels and may help to the long-term treatment of lymphedema (24).

So, exercise training is safe for cancer patients with lymphedema. Few previous studies showed no significant difference between the type of exercise training, but strength training had been considered in further studies. It is also recommended that resistance training have to be done with medium to high intensity. Furthermore, it is better to prescribe exercise training mode to cancer patient survivors with related lymphedema on the basis of personal preferences, survivorship concerns, and functional consideration. Some studies have reported the use of compression garments during training to be ineffective, while some others have found it to be useful.

Therefore, according to most studies, aerobic, resistance and stretching training programs had no influence on the volume and circumference of the arm in lymphedema cancer patients, but the training had a noticeable influence on the quality of life. As a final conclusion remark, it can be suggested that researchers consider training programs as treating methods instead of only controllers in lymphedema patients.

\section{References}

1. Cokkinides V, Albano J, Samuels A, Ward ME, Thum JM. American cancer society: Cancer facts and figures. Atlanta Am Cancer Soc. 2005.

2. Society C. C. Canadian Cancer Statistics. 2004. Available from: www.cancer.caccs/internet/mediareleaselist/0,3172_210504871_ 194634551_langId-en,00.html.

3. Jassem J, Buchanan M, Janicke F, Baum M, Cataliotti L, Kyriakides S, et al. The Hamburg statement: the partnership driving the European agenda on breast cancer. Eur J Cancer. 2004;40(12):1810-1. doi: 10.1016/j.ejca.2004.04.020. [PubMed: 15288281].

4. Ernst MF, Voogd AC, Balder W, Klinkenbijl JH, Roukema JA. Early and late morbidity associated with axillary levels I-III dissection in breast cancer. J Surg Oncol. 2002;79(3):151-5. discussion 156. [PubMed: 11870664].

5. Holli K, Pitkanen M, Jarvenpaa R, Rajala J, Lahtela S, Hyodynmaa S, et al. Early skin and lung reactions in breast cancer patients after radiotherapy: prospective study. Radiother Oncol. 2002;64(2):163-9. [PubMed: 12242126].

6. Rietman JS, Dijkstra PU, Hoekstra HJ, Eisma WH, Szabo BG, Groothoff $\mathrm{JW}$, et al. Late morbidity after treatment of breast cancer in relation to daily activities and quality of life: a systematic review. EurJSurg Oncol. 2003:29(3):229-38. [PubMed: 12657232].
7. Tasmuth T, von Smitten K, Hietanen P, Kataja M, Kalso E. Pain and other symptoms after different treatment modalities of breast cancer. Ann Oncol. 1995;6(5):453-9. [PubMed: 7669710].

8. Tengrup I, Tennvall-Nittby L, Christiansson I, Laurin M. Arm morbidity after breast-conserving therapy for breast cancer. Acta Oncol. 2000;39(3):393-7. [PubMed: 10987237].

9. Whelan TJ, Levine M, Julian J, Kirkbride P, Skingley P. The effects of radiation therapy on quality of life of women with breast carcinoma: results of a randomized trial. Ontario Clinical Oncology Group. Cancer. 2000;88(10):2260-6. [PubMed: 10820347].

10. Petrek JA, Senie RT, Peters M, Rosen PP. Lymphedema in a cohort of breast carcinoma survivors 20 years after diagnosis. Cancer 2001;92(6):1368-77. [PubMed: 11745212].

11. Hopwood P, Haviland JS, Sumo G, Mills J, Bliss JM, Yarnold JR, et al. Comparison of patient-reported breast, arm, and shoulder symptoms and body image after radiotherapy for early breast cancer: 5-year follow-up in the randomised Standardisation of Breast Radiotherapy(START) trials. Lancet Oncol.2010;11(3):231-40. doi: 10.1016/S1470-2045(09)70382-1. [PubMed: 20138809].

12. Mirolo BR, Bunce IH, Chapman M, Olsen T, Eliadis P, Hennessy JM, et al. Psychosocial benefits of postmastectomy lymphedema therapy. Cancer Nurs. 1995;18(3):197-205. [PubMed: 7600551].

13. Cheema BS, Gaul CA. Full-body exercise training improves fitness and quality of life in survivors of breast cancer. J Strength Cond Res. 2006;20(1):14-21. doi: 10.1519/R-17335.1. [PubMed: 16506861].

14. Schmitz KH, Ahmed RL, Hannan PJ, Yee D. Safety and efficacy of weight training in recent breast cancer survivors to alter body composition, insulin, and insulin-like growth factor axis proteins. Cancer Epidemiol Biomarkers Prev. 2005;14(7):1672-80. doi: 10.1158/1055-9965.EPI04-0736. [PubMed: 16030100 ].

15. Mackinnon LT. Chronic exercise training effects on immune function Med Sci Sports Exerc. 2000;32(7 Suppl):S369-76. [PubMed: 10910293].

16. Schneider CM, Hsieh CC, Sprod LK, Carter SD, Hayward R. Effects of supervised exercise training on cardiopulmonary function and fatigue in breast cancer survivors during and after treatment. Cancer. 2007;110(4):918-25. doi: 10.1002/cncr.22862. [PubMed: 17582616].

17. Ohira T, Schmitz KH, Ahmed RL, Yee D. Effects of weight training on quality of life in recent breast cancer survivors: the Weight Training for Breast Cancer Survivors (WTBS) study. Cancer. 2006;106(9):207683. doi: 10.1002/cncr.21829. [PubMed: 16568409].

18. Zaza S, Wright-De Aguero LK, Briss PA, Truman BI, Hopkins DP, Hennessy $\mathrm{MH}$, et al. Data collection instrument and procedure for systematic reviews in the Guide to Community Preventive Services. Task Force on Community Preventive Services. Am J Prev Med. 2000;18(1 Suppl):44-74. [PubMed: 10806979].

19. van der Windt DA, van der Heijden GJ, van den Berg SG, ter Riet G, de Winter AF, Bouter LM. Ultrasound therapy for musculoskeletal disorders: a systematic review. Pain. 1999;81(3):257-71. [PubMed: 10431713].

20. Courneya KS, Sellar CM, Stevinson C, McNeely ML, Peddle CJ, Friedenreich CM, et al. Randomized controlled trial of the effects of aerobic exercise on physical functioning and quality of life in lymphoma patients. J Clin Oncol. 2009;27(27):4605-12. doi 10.1200/JCO.2008.20.0634. [PubMed: 19687337].

21. Schmitz KH, Ahmed RL, Troxel AB, Cheville A, Lewis-Grant L, Smith $\mathrm{R}$, et al. Weight lifting for women at risk for breast cancer-related lymphedema: a randomized trial. JAMA. 2010;304(24):2699-705. doi: 10.1001/jama.2010.1837. [PubMed: 21148134].

22. Schmitz KH, Ahmed RL, Troxel A, Cheville A, Smith R, Lewis-Grant L, et al. Weight lifting in women with breast-cancer-related lymphedema. $N$ Engl J Med. 2009;361(7):664-73. doi: 10.1056/NEJMoa0810118. [PubMed: 19675330].

23. Sweeney C, Schmitz KH, Lazovich D, Virnig BA, Wallace RB, Folsom AR Functional limitations in elderly female cancer survivors. J Natl Cancer Inst. 2006;98(8):521-9. doi:10.1093/jnci/dji130. [PubMed: 16622121].

24. McKenzie DC, Kalda AL. Effect of upper extremity exercise on secondary lymphedema in breast cancer patients: a pilot study. 
Clin Oncol. 2003;21(3):463-6. doi: 10.1200/JCO.2003.04.069. [PubMed: 12560436].

25. Do JH, Kim W, Cho YK, Lee J, Song EJ, Chun YM, et al. Effects of Resistance Exercises and Complex Decongestive Therapy on Arm Function and Muscular Strength in Breast Cancer Related Lymphedema. Lymphology. 2015;48(4):184-96. [PubMed: 27164764].

26. Simonavice E, Kim JS, Panton L. Effects of resistance exercise in women with or at risk for breast cancer-related lymphedema. Support Care Cancer. 2017;25(1):9-15. doi: 10.1007/s00520-016-3374-0. [PubMed: 27516182].

27. Nelson NL. Breast Cancer-Related Lymphedema and Resistance Exercise: A Systematic Review. J Strength Cond Res. 2016;30(9):2656-65. doi: 10.1519/JSC.0000000000001355. [PubMed: 26840439].

28. Keilani M, Hasenoehrl T, Neubauer M, Crevenna R. Resistance exercise and secondary lymphedema in breast cancer survivors-a systematic review. Support Care Cancer. 2016;24(4):1907-16. doi: 10.1007/s00520015-3068-z. [PubMed: 26715294].

29. Singh B, Disipio T, Peake J, Hayes SC. Systematic Review and MetaAnalysis of the Effects of Exercise for Those With Cancer-Related Lymphedema. Arch Phys Med Rehabil. 2016;97(2):302-315 e13. doi: 10.1016/j.apmr.2015.09.012. [PubMed: 26440777].

30. Buchan J, Janda M, Box R, Schmitz K, Hayes S. A Randomized Trial on the Effect of Exercise Mode on Breast Cancer-Related Lymphedema. Med Sci Sports Exerc. 2016;48(10):1866-74. doi: 10.1249/MSS.0000000000000988. [PubMed: 27187092].

31. Bunce IH, Mirolo BR, Hennessy JM, Ward LC, Jones LC. Postmastectomy lymphoedema treatment and measurement. Med J Aust. 1994;161(2):125-8. [PubMed: 8028536].

32. Bok SK, Jeon Y, Hwang PS. Ultrasonographic Evaluation of the Effects of Progressive Resistive Exercise in Breast CancerRelated Lymphedema. Lymphat Res Biol. 2016;14(1):18-24. doi: 10.1089/lrb.2015.0021. [PubMed: 26824517].

33. Ahmed RL, Thomas W, Yee D, Schmitz KH. Randomized controlled trial of weight training and lymphedema in breast cancer survivors.J Clin
Oncol. 2006;24(18):2765-72. doi: 10.1200/JCO.2005.03.6749. [PubMed: 16702582].

34. Mortimer PS. Investigation and management of lymphoedema. Vasc Med Rev. 2017;vmr-1(1):1-20. doi: 10.1177/1358836x9000100102.

35. Mortimer PS. Managing lymphoedema. Clin Exp Dermatol. 1995;20(2):98-106. [PubMed: 8565266].

36. Witte MH, Witte CL. Lymphatics and blood vessels, lymphangiogenesis and hemangiogenesis: from cell biology to clinical medicine. Lymphology. 1987;20(4):257-66. [PubMed: 2451095].

37. Whittlinger H. Textbook of Dr. Vodder's manual of lymphatic drainage. Germany: Karl R. Haug Publishers; 1982.

38. Brennan MJ, Miller LT. Overview of treatment options and review of the current role and use of compression garments, intermittent pumps, and exercise in the management of lymphedema. Cancer. 1998;83(12 Suppl American):2821-7. [PubMed: 9874405].

39. Svensson WE, Mortimer PS, Tohno E, Cosgrove DO. Colour Doppler demonstrates venous flow abnormalities in breast cancer patients with chronic arm swelling. EurJ Cancer.1994;30A(5):657-60. [PubMed: 8080682].

40. Singh B, Buchan J, Box R, Janda M, Peake J, Purcell A, et al. Compression use during an exercise intervention and associated changes in breast cancer-related lymphedema. Asia Pac J Clin Oncol. 2016;12(3):216-24. doi: 10.1111/ajco.12471. [PubMed: 26935243].

41. Hamner JB, Fleming MD. Lymphedema therapy reduces the volume of edema and pain in patients with breast cancer. Ann Surg Oncol. 2007;14(6):1904-8. doi: 10.1245/s10434-006-9332-1. [PubMed: 17342565].

42. Courneya KS, Sellar CM, Stevinson C, McNeely ML, Friedenreich $\mathrm{CM}$, Peddle CJ, et al. Moderator effects in a randomized controlled trial of exercise training in lymphoma patients. Cancer Epidemiol Biomarkers Prev. 2009;18(10):2600-7. doi: 10.1158/1055-9965.EPI-090504. [PubMed: 19815635$]$.

43. McKenzie DC. Abreast in a boat-a race against breast cancer. CMAJ. 1998;159(4):376-8. [PubMed: 9732719]. 